\title{
Superior thermal stability and fast crystallization behavior of a novel, biodegradable a-methylated bacterial polyester
}

\author{
Sho Furutate ${ }^{1}$, Junichi Kamoi ${ }^{1}$, Christopher T. Nomura ${ }^{2}$, Seiichi Taguchi ${ }^{3}$, Hideki Abe ${ }^{4}$ and Takeharu Tsuge (i) ${ }^{1}$
}

\begin{abstract}
Given their ubiquity in modern society, the development of biodegradable and renewably sourced plastics is essential for the creation of an environmentally sustainable society. One of the drawbacks for currently available biodegradable plastics such as poly(L-lactic acid) (PLLA) and polyhydroxyalkanoates (PHAs) is that it is difficult to simultaneously achieve mechanical flexibility and certain crystallization behavior in these materials, which limits their use as replacements for established petroleum-based plastics such as isotactic polypropylene (iPP). Here, we report the synthesis and characterization of a new biodegradable plastic, poly(3-hydroxy-2-methylbutyrate) $[\mathrm{P}(3 \mathrm{H} 2 \mathrm{MB})]$, which is a member of the bacterial PHA family whose members include an a-methylated monomer unit. Biosynthesis of $\mathrm{P}(3 \mathrm{H} 2 \mathrm{MB})$ was achieved using recombinant Escherichia coli expressing an engineered pathway. Biosynthesized $\mathrm{P}(3 \mathrm{H} 2 \mathrm{MB})$ exhibited the highest melting temperature $\left(197^{\circ} \mathrm{C}\right)$ among the biosynthesized PHAs and improved thermal resistance. It also exhibited improved crystallization behavior and mechanical flexibility nearly equal to those of iPP. The primary nucleation rate of $\mathrm{P}(3 \mathrm{H} 2 \mathrm{MB})$ was faster than that of $\mathrm{P}(3 \mathrm{HB})$, and the spherulite morphology of $\mathrm{P}(3 \mathrm{H} 2 \mathrm{MB})$ was much finer than that of $\mathrm{P}(3 \mathrm{HB})$. This crystal morphology may result in more rapid crystallization behavior, increased transparency, and enhanced mechanical properties. The superior physical properties of $\mathrm{P}(3 \mathrm{H} 2 \mathrm{MB})$ have the potential to open new avenues for the production of high-performance biodegradable plastics for replacing petroleum-based bulk commodity plastics.
\end{abstract}

\section{Introduction}

The accumulation and prevalence of microplastics, defined by the National Oceanic and Atmospheric Administration (NOAA) as plastic particles $<5 \mathrm{~mm}$ in diameter, in the environment has become a global concern $^{1}$. As the supply, demand, and use of plastics increase, the probability of many nonbiodegradable plastic materials entering the environment also increases ${ }^{2}$. Although these materials are gradually broken into smaller particles via physical fragmentation, these fragments do not

\footnotetext{
Correspondence: Takeharu Tsuge (tsuge.t.aa@m.titech.ac.jp)

${ }^{1}$ Department of Materials Science and Engineering, Tokyo Institute of Technology, 4259 Nagatsuta, Midori-ku, Yokohama 226-8502, Japan

${ }^{2}$ Department of Biological Sciences, College of Science, University of Idaho, 875 Perimeter Dr., Moscow, ID 83844-3010, USA
}

Full list of author information is available at the end of the article biodegrade, resulting in a wide distribution throughout the oceans as microplastics. During this process, the total surface area of microplastics increases, enabling the adsorption of hydrophobic organic pollutants on their surface. Most of the microplastics found in aquatic environments have terrestrial origins ${ }^{3}$ but are accidentally released via runoff following storms. Additionally, microplastics such as scrubbers in cosmetic products and fibers from textiles continually enter wastewater treatment plants (WWTPs) ${ }^{4}$ and cannot be effectively removed, resulting in the release of a considerable amount of microplastics into aquatic environments ${ }^{5}$. This growing threat has led to renewed interest in finding biodegradable alternatives that can be degraded to chemical compounds (e.g., $\mathrm{CO}_{2}$ and $\mathrm{H}_{2} \mathrm{O}$ ) that can easily enter biogeochemical cycles to reduce their environmental impact. 
One key class of materials receiving attention as biodegradable alternatives to nonbiodegradable plastics are polyhydroxyalkanoates (PHAs). PHAs are aliphatic polyesters that can be produced in bacterial cells and act as carbon-storage materials in nature ${ }^{6}$. These materials can be produced via fermentation of biomass feedstocks, and most PHAs are satisfactorily biodegradable because they are provisional cellular storage materials that are easily catabolized by bacteria ${ }^{7}$. Importantly, PHAs are biodegradable in marine environments and have broad potential to combat the problems associated with nonbiodegradable microplastics ${ }^{8}$. The most widespread PHA found in nature is poly(3-hydroxybutyrate) $[\mathrm{P}(3 \mathrm{HB})]$, which is a crystalline thermoplastic polyester that has thermal properties similar to those of polypropylene. However, due to their thermal instability above the melting temperature $\left(T_{\mathrm{m}}\right)$, poor mechanical properties, and slow crystallization rate, $\mathrm{P}$ (3HB) and 3HB-based PHA copolymers have limited use as replacements for petroleum-based plastics ${ }^{6}$. The crystallization behavior affects the cycle time or production rate of plastic molding, such as injection molding, sheet extraction, and fiber spinning. In other words, the crystallization behavior is an important factor influencing the production cost and $\mathrm{CO}_{2}$ emission per unit product. Copolymerizing other PHA monomers, such as 3hydroxyhexanoate $(3 \mathrm{HHx})$ or 4-hydroxybutyrate, may improve the mechanical properties of 3HB-based PHA copolymers, but this process considerably extends the crystallization time ${ }^{6}$. Generally, for plastics, there is a trade-off between mechanical flexibility and crystallization. Poly(L-lactic acid) (PLLA) is another biodegradable polymer that is produced from renewable sources, and it is currently the polymer most widely used in the manufacture of biodegradable plastics. However, the exposure of PLLA to temperatures above the glass transition temperature $\left(T_{\mathrm{g}}\right)$ induces shrinkage and deformation, and its thermal resistance is low. Inducing crystallization of PLLA enhances the thermal resistance; however, the crystallization of PLLA is quite slow, and consequently, its processability is regarded as poor. The high glass-transition temperature of PLLA leads to poor mechanical properties and poor biodegradability ${ }^{9}$, limiting its overall use by plastic manufacturers. PLLA is not regarded as biodegradable except under industrial composting conditions and exhibits biodegradability at only high temperatures exceeding its glass transition temperature ${ }^{10}$.

To address the deficiencies encountered with currently characterized biobased biodegradable plastics, we sought to identify and produce biodegradable plastics with novel structures and physical properties that could be more widely adopted by manufacturers. Some heterotrophic bacteria found in activated sludge in WWTPs produce PHAs with unique chemical structures $^{11,12}$. In addition to $3 \mathrm{HB}$ monomers, these naturally produced PHAs are composed of 3-hydroxyvalerate $(3 \mathrm{HV})$ and $3 \mathrm{HHx}$, and moreover, $\alpha$-methylated monomers such as 3-hydroxy-2-methylbutyrate (3H2MB) and 3-hydroxy-2-methylvalerate (3H2MV) have been used in copolymers. A $3 \mathrm{H} 2 \mathrm{MB}$-containing PHA copolymer was produced by naturally occurring bacteria in a mixed culture from activated sludge, where the copolymer consisted of up to $13 \mathrm{~mol} \% 3 \mathrm{H} 2 \mathrm{MB}$ units as a monomer of a quaternary copolymer ${ }^{12}$. Because of the relatively low concentration of the $3 \mathrm{H} 2 \mathrm{MB}$ monomer in these naturally produced PHA copolymers, the properties of PHAs composed mainly of $3 \mathrm{H} 2 \mathrm{MB}$ have not been well defined. Additionally, the bacterial species and the enzymes capable of incorporating $3 \mathrm{H} 2 \mathrm{MB}$ into $\mathrm{PHA}$ have not been identified ${ }^{13}$.

In a previous study, we biosynthesized PHA copolymers of $3 \mathrm{H} 2 \mathrm{MB}$ and $3 \mathrm{HB}$ by using genetically engineered Escherichia coli ${ }^{14}$. However, even in this case, the $3 \mathrm{H} 2 \mathrm{MB}$ ratio was limited to $34 \mathrm{~mol} \%$, and the copolymer comprised a mixture of copolymers with various $3 \mathrm{H} 2 \mathrm{MB}$ ratios. In another study, 3H2MB-containing PHA was biosynthesized via Claisen condensation by a thiolase, and the $3 \mathrm{H} 2 \mathrm{MB}$ ratio of this polymer was also limited to $32 \mathrm{~mol} \%{ }^{15}$. In this study, we overcome the shortcomings of previous studies to control the $3 \mathrm{H} 2 \mathrm{MB}$ composition of PHA polymers and develop a system to produce a novel $\mathrm{P}(3 \mathrm{H} 2 \mathrm{MB})$ homopolymer. By elucidating its precise thermal and mechanical properties, we demonstrate the great potential for this material to replace conventional nonbiodegradable plastics.

\section{Materials and methods \\ Materials}

The isotactic $\mathrm{P}(3 \mathrm{HB})$ homopolymer used in this study was biosynthesized by Ralstonia eutropha H16. The molecular weight of $\mathrm{P}(3 \mathrm{HB})$ was $M_{\mathrm{n}}=2.3 \times 10^{5}\left(M_{\mathrm{w}} / M_{\mathrm{n}}=\right.$ $2.3)$, as measured by gel permeation chromatography (GPC). Isotactic polypropylene (iPP) was purchased from Sigma-Aldrich (St. Louis, MO, USA) and used as received. The molecular weights of iPP were $M_{\mathrm{n}} \sim 97,000$ and $M_{\mathrm{w}} \sim$ 340,000. To obtain film samples, the iPP pellets were melted at $220^{\circ} \mathrm{C}$ and pressed using a hot-press apparatus H300-01 (AsOne Corporation, Osaka, Japan). Poly(L-lactic acid) (Ingeo 3260HP; high-crystallinity grade, consisting of L-lactic acid $>99.5 \mathrm{~mol} \%$ ) was obtained from NatureWorks LLC (Minnetonka, MN, USA). PLLA was dissolved in chloroform $\left(\mathrm{CHCl}_{3}\right)$ and cast to obtain a cast film. Further details for $\mathrm{P}(3 \mathrm{H} 2 \mathrm{MB})$ are given in subsequent sections.

\section{Bacterial strains and plasmids}

E. coli LSBJ, a $f a d B$ fadJ double-deletion mutant of E. coli LS5218 [fadR601, atoC(Con)], was used as the host strain for PHA biosynthesis ${ }^{16,17}$. A plasmid harboring the PHA biosynthetic operon from Aeromonas caviae was 
introduced into $E$. coli LSBJ. The operon consists of a PHA granule-associated protein gene $\left(p h a P_{\mathrm{Ac}}\right)$, a PHA synthase gene $\left(p h a C_{\mathrm{Ac}}\right)$, and an $(R)$-specific enoyl-CoA hydratase gene $\left(p h a J_{\mathrm{Ac}}\right)$. To efficiently polymerize $\mathrm{P}$ (3H2MB), N149S, and D171G point mutations were introduced in $\mathrm{PhaC}_{\mathrm{Ac}}$, and a $\mathrm{D} 4 \mathrm{~N}$ point mutation was introduced in $\mathrm{PhaP}_{\mathrm{Ac}} 14,17,18$. To enhance the supply of 3H2MB-CoA, a pTTQ vector containing the propionylCoA transferase (PCT) gene from Megasphaera elsdenii $(p c t)$ was also introduced into strain LSBJ ${ }^{19}$.

\section{Biosynthesis of $\mathrm{P}(3 \mathrm{H} 2 \mathrm{MB})$}

Recombinant $E$. coli LSBJ was first cultivated for $15 \mathrm{~h}$ at $37^{\circ} \mathrm{C}$ with reciprocal shaking $(160 \mathrm{rpm})$ in a $50 \mathrm{~mL}$ flask containing $20 \mathrm{~mL}$ of lysogeny broth (LB) medium (Supplementary Scheme 1) until the OD reached $\sim 5-6$. LB contained $10 \mathrm{~g} / \mathrm{L}$ Bacto-tryptone (Difco Laboratories, Detroit, MI, USA), $5 \mathrm{~g} / \mathrm{L}$ Bacto-yeast extract (Difco Laboratories), and $10 \mathrm{~g} / \mathrm{L} \mathrm{NaCl}$. In addition, $50 \mathrm{mg} / \mathrm{L}$ kanamycin and $50 \mathrm{mg} / \mathrm{L}$ carbenicillin were added for plasmid maintenance during preculture. A $5 \mathrm{~mL}$ aliquot of the preculture broth was inoculated into $100 \mathrm{~mL}$ (final volume) of M9-modified medium in a $500 \mathrm{~mL}$ shaking flask and cultivated for $4 \mathrm{~h}$ at $30^{\circ} \mathrm{C}$ with reciprocal shaking (130 rpm). This $\mathrm{M}^{20}{ }^{20}$-modified medium contained $17.1 \mathrm{~g} / \mathrm{L}$ $\mathrm{Na}_{2} \mathrm{HPO}_{4} \cdot 12 \mathrm{H}_{2} \mathrm{O}, 3 \mathrm{~g} / \mathrm{L} \mathrm{KH}_{2} \mathrm{PO}_{4}, 0.5 \mathrm{~g} / \mathrm{L} \mathrm{NaCl}, 2 \mathrm{~mL}$ of $1 \mathrm{M} \mathrm{MgSO}_{4} \cdot 7 \mathrm{H}_{2} \mathrm{O}, 0.1 \mathrm{~mL}$ of $1 \mathrm{M} \mathrm{CaCl}$, and $2.5 \mathrm{~g} / \mathrm{L}$ Bacto-yeast extract. For plasmid maintenance during cultivation, $50 \mathrm{mg} / \mathrm{L}$ kanamycin and $50 \mathrm{mg} / \mathrm{L}$ carbenicillin were added. trans-2-Methylbut-2-enoic acid (tiglic acid) was used as the $3 \mathrm{H} 2 \mathrm{MB}$ precursor. Tiglic acid inhibited cell growth, whereas a high glucose concentration caused catabolic repression of PHA biosynthetic genes induced by isopropyl- $\beta$-D-thiogalactopyraniside (IPTG). Therefore, tiglic acid and glucose were fed into the system three times to maintain the concentrations at low levels. After $4 \mathrm{~h}$ of cultivation, $1.25 \mathrm{~g} / \mathrm{L}$ glucose, $2 \mathrm{~g} / \mathrm{L}$ tiglic acid, and $1 \mathrm{mM}$ IPTG were added. To enhance the biosynthesis of the $\mathrm{P}$ (3H2MB) homopolymer, $1.25 \mathrm{~g} / \mathrm{L}$ glucose and $2 \mathrm{~g} / \mathrm{L}$ tiglic acid were fed to the bacteria at 28 and $52 \mathrm{~h}$. Cultivation was continued for $72 \mathrm{~h}$ after the first addition of tiglic acid and glucose. After cultivation, the cells were harvested by centrifugation and lyophilized. PHA was extracted from the lyophilized cells by immersion in $\mathrm{CHCl}_{3}$ at $60^{\circ} \mathrm{C}$ for $6 \mathrm{~h}$ and then at room temperature for 3 days. The polymer $\mathrm{CHCl}_{3}$ solution was poured into hexane, and the precipitated polymer was collected by filtration using filter paper. The polymers were purified by reprecipitation with methanol and hexane.

\section{Characterization of $\mathrm{P}(3 \mathrm{H} 2 \mathrm{MB})$ \\ Nuclear magnetic resonance (NMR) analysis}

The compositions and chemical structure of the PHAs in this study were determined by NMR (Biospin AVANCE
III 400A, Bruker, Billerica, MA, USA). The polymers were dissolved in $\mathrm{CDCl}_{3}$, and the composition was determined from integration of the peaks in $400 \mathrm{MHz}{ }^{1} \mathrm{H}$ NMR spectra. The peak assignment was confirmed by $\mathrm{HH}-$ COSY. The isotacticity of the polymer was evaluated by $100 \mathrm{MHz}{ }^{13} \mathrm{C}$ NMR.

\section{Gel permeation chromatography}

The molecular weights of the PHAs were determined using a 10A GPC system (Shimadzu, Kyoto, Japan). The polymers were dissolved in $\mathrm{CHCl}_{3}$ and separated by two K-806M-joined columns (Shodex, Tokyo, Japan) at $40{ }^{\circ} \mathrm{C}$.

\section{Differential scanning calorimetry (DSC)}

DSC was conducted using a Pyris 1 instrument (PerkinElmer, Waltham, MA, USA) equipped with a liquid nitrogen cooling system under a helium gas atmosphere. To determine the melting temperature $\left(T_{\mathrm{m}}\right)$, cold crystallization temperature $\left(T_{\mathrm{cc}}\right), T_{\mathrm{g}}$, and enthalpy of fusion $\left(\Delta H_{m}\right)$, the polymers were first heated to $220^{\circ} \mathrm{C}$ at a rate of $20^{\circ} \mathrm{C} / \mathrm{min}$, cooled steeply (at a rate of $\sim 300^{\circ} \mathrm{C} / \mathrm{min}$ ) to $-50^{\circ} \mathrm{C}$ and then heated again at a rate of $20^{\circ} \mathrm{C} / \mathrm{min} . T_{\mathrm{m}}$, $T_{\mathrm{cc}}, T_{\mathrm{g}}$, and $\Delta H_{m}$ were determined from the second heating scan of the DSC thermogram. To determine the crystallization temperature $\left(T_{\mathrm{c}}\right)$ from the cooling step, the cooling rate was set at $20^{\circ} \mathrm{C} / \mathrm{min}$.

The crystallization kinetics were analyzed by isothermal crystallization analysis using DSC. The polymers were heated at $220^{\circ} \mathrm{C}$ and then quench-cooled to the isothermal crystallization temperature $\left(T_{\text {iso }}\right)$, the exothermal heat flow was measured, and the half-crystallization time $\left(t_{1 / 2}\right)$, Avrami constant $k$, and Avrami index $n$ were determined.

To evaluate the thermal stability of $\mathrm{P}(3 \mathrm{H} 2 \mathrm{MB})$, cyclic DSC was conducted. First, the polymer was heated to $220^{\circ} \mathrm{C}$ at a heating rate of $20^{\circ} \mathrm{C} / \mathrm{min}$ and then cooled to $0{ }^{\circ} \mathrm{C}$ at a cooling rate of $20^{\circ} \mathrm{C} / \mathrm{min}$. The polymer was then heated again to $220^{\circ} \mathrm{C}$ at a heating rate of $20^{\circ} \mathrm{C} / \mathrm{min}$. The polymer was melted and recrystallized repeatedly four times, and the changes in the melting point and molecular weight were measured. The measurements were performed under a helium atmosphere.

\section{Polarized optical microscopy (POM)}

The morphology and growth of the spherulites were observed with an optical microscope (BX51, Olympus, Tokyo, Japan) equipped with crossed polarizers and a Linkam hot stage. The solvent cast film was first heated to $220^{\circ} \mathrm{C}$ at $80^{\circ} \mathrm{C} / \mathrm{min}$ on the hot stage and held at that temperature for $1 \mathrm{~min}$. The sample was then quenched to $T_{\text {iso }}$ at a rate of $80^{\circ} \mathrm{C} / \mathrm{min}$. The sample was crystallized isothermally at a given $T_{\text {iso }}$ to monitor the growth of spherulites as a function of time. Polarized optical microscopic photographs were taken every $5 \mathrm{~s}$, and the 
radial growth rate of the spherulites was calculated from the slope of the spherulite radius versus time plot.

The primary nucleation rates $(I)$ of $\mathrm{P}(3 \mathrm{HB})$ and $\mathrm{P}$ (3H2MB) were evaluated from the spherulite growth rates $(G)$ and Avrami constants $(k)$ using the equation below:

$$
I=\frac{3 k}{\pi G^{3}}
$$

Here, $k$ was obtained from isothermal crystallization analysis by DSC when the Avrami index $(n)$ was $\sim 4$ and the crystallization proceeded homogeneously and threedimensionally.

\section{Mechanical properties}

Stress-strain tests of the $\mathrm{CHCl}_{3}$ solution cast films were performed at room temperature using a Shimadzu EZ test machine. $\mathrm{P}(3 \mathrm{H} 2 \mathrm{MB})$ and $\mathrm{P}(3 \mathrm{HB})$ were dissolved in $\mathrm{CHCl}_{3}$ and cast in a Petri dish. After evaporating the $\mathrm{CHCl}_{3}$, the cast films were conditioned for 3 weeks at ambient temperature until the secondary crystallization reached equilibrium. The sample was $\sim 100 \mu \mathrm{m}$ thick and cut into dimensions of $5 \mathrm{~mm} \times 20 \mathrm{~mm}$. To fix the film and confirm a firm grip by the machine, paper and double-sided tape were inserted between the film and the grip surface. The gauge length was set to $10 \mathrm{~mm}$. The strain rate was set at $10 \mathrm{~mm} / \mathrm{min}$; the data shown are the averages of at least three measurements.

\section{Evaluation of the biodegradation of 3H2MB-rich polymer}

The ability of microorganisms from the environment to hydrolyze the $3 \mathrm{H} 2 \mathrm{MB}$ polymer was evaluated by analyzing the formation of a clear zone around the colonies on agar plates supplemented with a polymer suspension as the sole carbon source ${ }^{21}$. The assay plates contained medium with suspended polymer and $1.5 \mathrm{~g} / \mathrm{L}$ agar. The medium with polymer contained $11.6 \mathrm{~g} / \mathrm{L} \mathrm{Na}_{2} \mathrm{HPO}_{4} \cdot 12 \mathrm{H}_{2} \mathrm{O}, 4.6 \mathrm{~g} / \mathrm{L}$ $\mathrm{KH}_{2} \mathrm{PO}_{4}, 1.0 \mathrm{~g} / \mathrm{L} \mathrm{NH} \mathrm{NH}_{4} \mathrm{Cl} 0.5 \mathrm{~g} / \mathrm{L} \mathrm{MgSO}_{4} \cdot 7 \mathrm{H}_{2} \mathrm{O}, 0.05 \mathrm{~g} / \mathrm{L}$ $\mathrm{CaCl}_{2}, 0.06 \mathrm{~g} / \mathrm{L} \mathrm{FeCl}_{3}$, and $2.0 \mathrm{~g} / \mathrm{L}$ polyester powder. For efficient and high-throughput screening of microorganisms, a low-molecular-weight $3 \mathrm{H} 2 \mathrm{MB}$-rich polymer was synthesized from the $\mathrm{P}(3 \mathrm{H} 2 \mathrm{MB}-\mathrm{co}-3 \mathrm{HB})$ copolymer and used as the polyester powder. For this process, a copolymer $\left(3 \mathrm{H} 2 \mathrm{MB} \sim 90 \mathrm{~mol} \%, M_{\mathrm{w}}=1.2 \times 10^{5}, M_{\mathrm{w}} / M_{\mathrm{n}}=2.4\right)$ biosynthesized by recombinant $E$. coli LSBJ cells that were fed $1 \mathrm{~g} / \mathrm{L}$ glucose, $2 \mathrm{~g} / \mathrm{L}$ tiglic acid, and $0.02 \mathrm{~g} / \mathrm{L}(2 E)$-but2 -enoic acid (crotonic acid) as a $3 \mathrm{HB}$ precursor (at 4 and $28 \mathrm{~h}$ of cultivation) was added to increase the copolymer yield by dissolution in $\mathrm{CHCl}_{3}$ and reaction with $15 \%(\mathrm{v} / \mathrm{v})$ sulfuric acid/methanol at $100^{\circ} \mathrm{C}$ for $1 \mathrm{~h}$. The polymer was precipitated in methanol, and a fine powder of $3 \mathrm{H} 2 \mathrm{MB}$-rich polymer $\left(3 \mathrm{H} 2 \mathrm{MB} \sim 92 \mathrm{~mol} \%, M_{\mathrm{n}} \sim 7000\right)$ was obtained.

Environmental microbial consortia were obtained from soil in Nagatsuta, Yokohama, Japan. To selectively propagate
3H2MB-polymer-degrading bacteria, the microbial consortia were first cultivated in polymer-suspended liquid medium containing $3 \mathrm{H} 2 \mathrm{MB}$-rich polymer as the sole carbon source. The flasks containing the microbial consortia were shaken at $30^{\circ} \mathrm{C}$ for $2-7$ days. The cultured microbial consortia were transferred to agar plates with suspended polymer. After incubation at $30^{\circ} \mathrm{C}$ for several days, some colonies that formed a clear zone were selected as 3H2MBpolymer-degrading strains.

\section{Results \\ Biosynthesis of $\mathrm{P}(3 \mathrm{H} 2 \mathrm{MB})$ homopolymer}

To produce a $\mathrm{P}(3 \mathrm{H} 2 \mathrm{MB})$ homopolymer, additional genetic modification of our original bacterial chassis was necessary. This required the use of the $E$. coli strain LSBJ [fadR601, atoC(Con), $\Delta f a d B, \Delta f a d]$ as a chassis. Previous studies have demonstrated that $E$. coli LSBJ produces various types of PHA homopolymers and copolymers with defined repeating unit compositions ${ }^{16,22,23}$. Additionally, to activate the monomer and polymerize the $\mathrm{P}(3 \mathrm{H} 2 \mathrm{MB})$ homopolymer, three additional enzymes were used, namely, PCT from M. elsdenii, which has been used successfully to activate lactyl-CoA for in vivo polymerization, and (R)specific enoyl-CoA hydratase $\left(\mathrm{PhaJ}_{\mathrm{Ac}}\right)$ and PHA synthase $\left(\mathrm{PhaC}_{\mathrm{Ac}}\right)$ from A. caviae, which have been used to successfully produce PHA polymers (Fig. 1A) ${ }^{17}$. Tiglic acid was added as the precursor of the $3 \mathrm{H} 2 \mathrm{MB}$ monomer. Tiglic acid is converted to tiglyl-CoA by $\mathrm{PCT}$, hydrated to $3 \mathrm{H} 2 \mathrm{MB}-$ CoA by $\mathrm{PhaJ}_{\mathrm{Ac}}$, and then polymerized to form $\mathrm{P}(3 \mathrm{H} 2 \mathrm{MB})$ by $\mathrm{PhaC}_{\mathrm{Ac}}$. Glucose was fed to support cell growth. By deleting the $f a d B$ and $f a d J$ genes, it was possible to prevent the decomposition of tiglic acid during $\beta$-oxidation. The $\mathrm{P}(3 \mathrm{H} 2 \mathrm{MB})$ homopolymer was biosynthesized using an optimized substrate feeding protocol for this strain, and $0.22 \mathrm{~g} / \mathrm{L}$ of $\mathrm{P}(3 \mathrm{H} 2 \mathrm{MB})$ homopolymer was obtained from $1.05 \mathrm{~g} / \mathrm{L}$ dry cell weight. Approximately $4 \%$ of the supplemented tiglic acid was converted to $\mathrm{P}(3 \mathrm{H} 2 \mathrm{MB})$.

\section{Characterization of $\mathrm{P}(3 \mathrm{H} 2 \mathrm{MB})$ films}

To utilize PHA materials as substitutes for traditional petroleum-based plastics, it is necessary to define the physical properties and confirm the adaptability of the materials to industrial processing. Thus, we performed an in-depth characterization of these properties for $\mathrm{P}$ (3H2MB). The $\mathrm{P}(3 \mathrm{H} 2 \mathrm{MB})$ homopolymer was extracted from freeze-dried cells, and solvent cast films were prepared (Fig. 1B). The films were generally transparent, with slight opacity. The molecular weight of the $\mathrm{P}(3 \mathrm{H} 2 \mathrm{MB})$ homopolymer, as measured by GPC, was $M_{\mathrm{n}}=15.1 \times 10^{4}$ with $M_{\mathrm{w}} / M_{\mathrm{n}}=2.77$ (Table 1).

Tensile tests showed that the $\mathrm{P}(3 \mathrm{H} 2 \mathrm{MB})$ cast films were highly ductile compared to $\mathrm{P}(3 \mathrm{HB})$ cast films (Table 1 ). The elongation at break (520\%) was significantly higher than that of $\mathrm{P}(3 \mathrm{HB})(12 \%)$ and comparable to that of iPP 
A<smiles>CC=C(C(=O)O)C(=O)O</smiles>

Acetyl-CoA

Tiglic acid

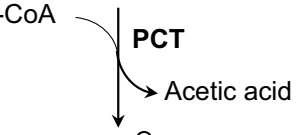<smiles>CC=C(C)C(=O)S(=O)(=O)O</smiles><smiles>CC(CO)C(C)c1ccccc1</smiles><smiles>C[C@H](O)[C@@H](C)C(=O)S(=O)(=O)O</smiles>

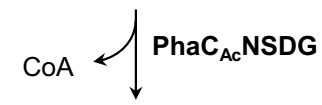<smiles>C[C@@H](OC(C)(C)C)[C@@H](C)C(=O)C(C)(C)C</smiles>

B

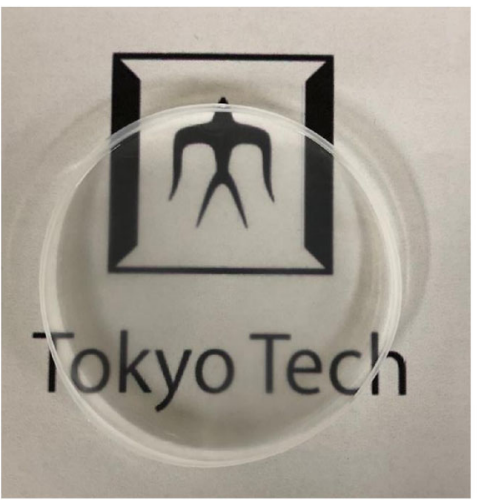

C

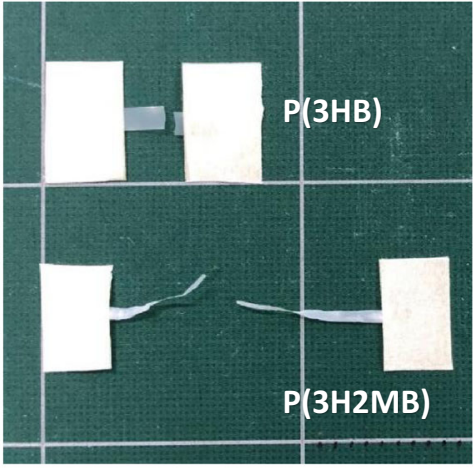

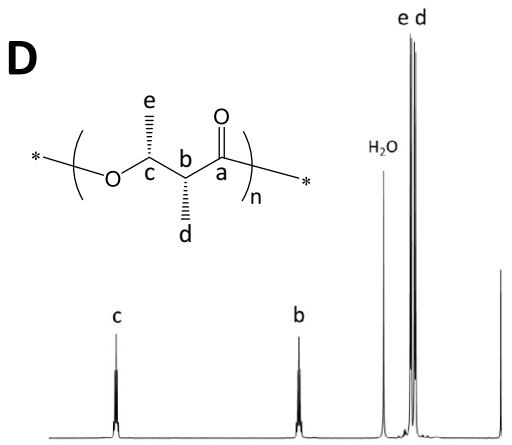

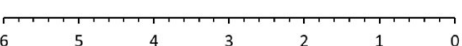

Chemical shift (ppm)

$\mathbf{E}$

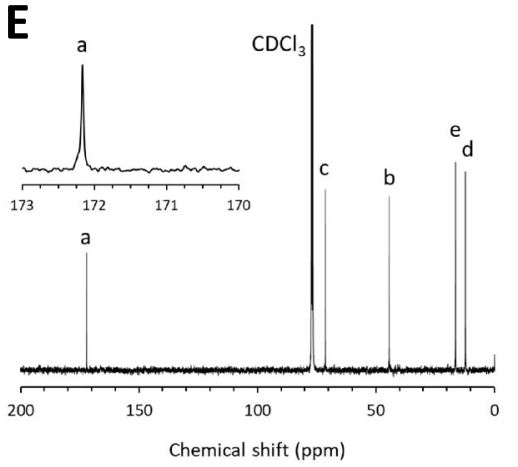

Fig. 1 Biosynthesis and characterization of $\mathbf{P}(3 \mathrm{H} 2 \mathrm{MB})$ homopolymer. A Pathway for biosynthesis of $\mathrm{P}(3 \mathrm{H} 2 \mathrm{MB})$ constructed in E. coli LSBJ. PCT: M. elsdenii propionyl-CoA transferase, PhaJ Ac: $_{\text {C }}$. caviae (R)-specific enoyl-CoA hydratase, PhaC $\mathrm{C}_{\mathrm{Ac}}$ : A. caviae PHA synthase (NSDG mutant). B Photograph of $\mathrm{P}(3 \mathrm{H} 2 \mathrm{MB})$ solution cast film. $\mathbf{C ~} \mathrm{P}(3 \mathrm{HB})$ and $\mathrm{P}(3 \mathrm{H} 2 \mathrm{MB})$ cast films after stretching. $\mathbf{D} 400 \mathrm{MHz}{ }^{1} \mathrm{H}$ NMR spectrum of the $\mathrm{P}(3 \mathrm{H} 2 \mathrm{MB})$ homopolymer. E $100 \mathrm{MHz}{ }^{13} \mathrm{C}$ NMR spectrum of $\mathrm{P}(3 \mathrm{H} 2 \mathrm{MB})$ homopolymer with expanded spectrum.

Table 1 Comparison of thermal and mechanical properties of polymers.

\begin{tabular}{|c|c|c|c|c|c|c|c|c|c|c|c|c|}
\hline Polymer & $\begin{array}{l}M_{\mathrm{n}} \\
\left(\times 10^{4}\right)\end{array}$ & $\begin{array}{l}M_{\mathrm{w}} / \\
M_{\mathrm{n}}\end{array}$ & $\begin{array}{l}T_{\mathrm{g}} \\
\left({ }^{\circ} \mathrm{C}\right)\end{array}$ & $\begin{array}{l}T_{\mathrm{m}} \\
\left({ }^{\circ} \mathrm{C}\right)\end{array}$ & $\begin{array}{l}T_{\mathrm{m}}{ }^{\circ} \\
\left({ }^{\circ} \mathrm{C}\right)^{\mathrm{a}}\end{array}$ & $\begin{array}{l}\Delta H_{\mathrm{m}} \\
(\mathrm{J} / \mathrm{g})\end{array}$ & $\begin{array}{l}\Delta H_{\mathrm{m}}{ }^{\circ} \\
(\mathrm{J} / \mathrm{g})^{\mathrm{b}}\end{array}$ & $\begin{array}{l}T_{\mathrm{d} 5} \\
\left({ }^{\circ} \mathrm{C}\right)^{\mathrm{c}}\end{array}$ & $\begin{array}{l}T_{\mathrm{d} \_\max } \\
\left({ }^{\circ} \mathrm{C}\right)^{\mathrm{c}}\end{array}$ & $\begin{array}{l}\text { Young's } \\
\text { modulus (MPa) }\end{array}$ & $\begin{array}{l}\text { Tensile } \\
\text { strength (MPa) }\end{array}$ & $\begin{array}{l}\text { Elongation at } \\
\text { break (\%) }\end{array}$ \\
\hline$P(3 \mathrm{HB})$ & 22.8 & 2.30 & 4 & 176 & 196 & 79 & 129 & 257 & 292 & $1420 \pm 80$ & $58 \pm 7$ & $12 \pm 0$ \\
\hline $\mathrm{P}(3 \mathrm{H} 2 \mathrm{MB})$ & 15.1 & 2.77 & 15 & 197 & 220 & 47 & 88 & 278 & 304 & $583 \pm 64$ & $37 \pm 2$ & $520 \pm 117$ \\
\hline iPP & 9.7 & 3.5 & $-10^{d}$ & 166 & $208^{d}$ & 71 & $148^{d}$ & - & - & $1700^{d}$ & $38^{d}$ & $400^{d}$ \\
\hline PLLA & 10.9 & 1.7 & 59 & 174 & $207^{e}$ & 41 & $93.7^{e}$ & - & - & $2600^{e}$ & $57^{e}$ & $3^{e}$ \\
\hline
\end{tabular}

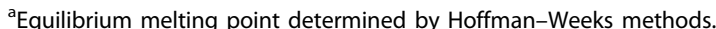

${ }^{b}$ Equilibrium fusion enthalpy determined for $100 \%$ crystallinity, calculated from DSC and XRD data.

${ }^{\mathrm{c}} T_{\mathrm{d} 5}$ : temperature at $5 \%$ weight loss, $T_{\mathrm{d} \_ \text {max }}$ : temperature at the highest weight loss rate during thermal decomposition, measured using TG-DTA.

${ }^{\mathrm{d}}$ Data obtained from refs. ${ }^{24,25}$.

eData obtained from refs. ${ }^{26,40}$.

$(400 \%)^{24,25}$ (Fig. 1C). Although $\mathrm{P}(3 \mathrm{H} 2 \mathrm{MB})$ exhibited a considerably higher elongation to break than $\mathrm{P}(3 \mathrm{HB})$ and PLLA, its Young's modulus was lower ${ }^{26}$. The brittleness of bioplastics is regarded as one of the major obstacles to their practical use; thus, the high ductility of $\mathrm{P}(3 \mathrm{H} 2 \mathrm{MB})$ represents its significant advantage over currently available bioplastics.

\section{Stereoregularity of $\mathrm{P}(3 \mathrm{H} 2 \mathrm{MB})$ biosynthesized from tiglic} acid

NMR analysis was used to accurately characterize the molecular structure of the $\mathrm{P}(3 \mathrm{H} 2 \mathrm{MB})$ homopolymer (Fig. 1D and E). ${ }^{13} \mathrm{C}$ NMR analysis indicated that the homopolymer was highly isotactic, consisting of a single enantiomer. The methyl ester of $3 \mathrm{H} 2 \mathrm{MB}$ obtained by 
methanolysis of the $\mathrm{P}(3 \mathrm{H} 2 \mathrm{MB})$ homopolymer (Supplementary Fig. 1) exhibited a negative specific optical rotation $\left([\alpha]^{\mathrm{D}}{ }_{20}=-11.0^{\circ}, c=1.0\right.$ in $\left.\mathrm{CDCl}_{3}\right)$. Among the four enantiomers of $3 \mathrm{H} 2 \mathrm{MB}$, the enantiomer that was polymerized by PHA synthase ( $3 R$ enantiomer) and whose methyl ester has negative specific optical rotation corresponded to only $(2 R, 3 R)-3 \mathrm{H} 2 \mathrm{MB}$ based on the results of a previous study ${ }^{27}$. Therefore, the biosynthesized isotactic homopolymer was $\mathrm{P}[(2 R, 3 R)-3 \mathrm{H} 2 \mathrm{MB}]$, which is consistent with the stereochemistry of the monomer supplied by the enzyme $\mathrm{PhaJ}_{\mathrm{Ac}}{ }^{28}$.

\section{Melting behavior of $\mathrm{P}(3 \mathrm{H} 2 \mathrm{MB})$}

The thermal properties of the $\mathrm{P}(3 \mathrm{H} 2 \mathrm{MB})$ homopolymer were characterized by DSC. The melting temperature $\left(T_{\mathrm{m}}\right)$ of the $\mathrm{P}(3 \mathrm{H} 2 \mathrm{MB})$ homopolymer $\left(197^{\circ} \mathrm{C}\right)$ was higher than that of $\mathrm{P}(3 \mathrm{HB})\left(176^{\circ} \mathrm{C}\right)$ (Fig. $\left.2 \mathrm{~A}\right)$. According to Hoffman-Weeks analysis (Supplementary Fig. 2), the equilibrium melting temperature $\left(T_{\mathrm{m}}{ }^{\circ}\right)$ was determined to be $220^{\circ} \mathrm{C}, \sim 24^{\circ} \mathrm{C}$ higher than that of $\mathrm{P}(3 \mathrm{HB})\left(196^{\circ} \mathrm{C}\right)^{29}$. The $T_{\mathrm{m}}{ }^{\circ}$ observed for $\mathrm{P}(3 \mathrm{H} 2 \mathrm{MB})$ is the highest among those of all the biosynthesized PHAs reported to date ${ }^{7}$. Even when $\mathrm{P}(3 \mathrm{H} 2 \mathrm{MB})$ was quenched at a cooling rate higher than $300^{\circ} \mathrm{C} / \mathrm{min}$ from the melt at $220^{\circ} \mathrm{C}$, crystallization was completed during quenching, which resulted in an undetectable cold crystallization temperature $\left(T_{\mathrm{cc}}\right)$ and an undetectable $T_{\mathrm{g}}$ in the second heating thermogram. This phenomenon indicates that $\mathrm{P}(3 \mathrm{H} 2 \mathrm{MB})$ crystallizes very rapidly compared to $\mathrm{P}(3 \mathrm{HB})$ and other PHAs. To determine the $T_{\mathrm{g}}$ of $\mathrm{P}(3 \mathrm{H} 2 \mathrm{MB})$, the sample was quenched from the melt at $220^{\circ} \mathrm{C}$ by immediate immersion in liquid nitrogen. The $T_{\mathrm{g}}$ of $\mathrm{P}(3 \mathrm{H} 2 \mathrm{MB})$ was observed at $15^{\circ} \mathrm{C}$ (Supplementary Fig. 3), which is $11^{\circ} \mathrm{C}$ higher than that of $\mathrm{P}(3 \mathrm{HB})$ (Fig. 2A). In the case of PHAs, as the carbon number of the $\beta$-alkyl group increases, $T_{\mathrm{g}}$ and $T_{\mathrm{m}}$ decrease. However, when a methyl group was introduced on the $\alpha$-carbon, the $T_{\mathrm{g}}$ and $T_{\mathrm{m}}$ anomalously increased. In a previous study ${ }^{14,15}$, PHA containing $3 \mathrm{H} 2 \mathrm{MB}$ as a comonomer exhibited a lower $T_{\mathrm{g}}$ than $\mathrm{P}(3 \mathrm{HB})$ and was amorphous. These thermal properties may be derived from copolymerization with other monomers, such as $3 \mathrm{HV}$ or $3 \mathrm{H} 2 \mathrm{MV}$. The fusion enthalpy of $\mathrm{P}(3 \mathrm{H} 2 \mathrm{MB})$ observed in the heating scan was smaller $\left(\Delta H_{\mathrm{m}}=47 \mathrm{~J} / \mathrm{g}\right)$ than that of the $\mathrm{P}(3 \mathrm{HB})$ homopolymer $\left(\Delta H_{\mathrm{m}}=79 \mathrm{~J} / \mathrm{g}\right)$. However, the degrees of crystallinity of $\mathrm{P}(3 \mathrm{H} 2 \mathrm{MB})$ and $\mathrm{P}$ (3HB) determined by X-ray diffraction (XRD) were $63 \%$ and $65 \%$, respectively, which are comparable (Supplementary Fig. 4). The higher flexibility of $\mathrm{P}(3 \mathrm{H} 2 \mathrm{MB})$ compared to that of $\mathrm{P}(3 \mathrm{HB})$, based on Young's modulus, may be derived from the lower fusion enthalpy of the former. In other words, fewer interactions between molecular chains in the crystal result in the greater flexibility of $\mathrm{P}(3 \mathrm{H} 2 \mathrm{MB})$. The difference between the $T_{\mathrm{m}}$ and the crystallization temperature $\left(T_{\mathrm{c}}\right)$ detected in the cooling scan is defined as $\Delta T$. Generally, $\Delta T$ is considered an important index for polymer processing, and a smaller $\Delta T$ indicates faster crystallization behavior ${ }^{30}$. The $\Delta T$ values of the $\mathrm{P}(3 \mathrm{HB})$ and $\mathrm{P}(3 \mathrm{H} 2 \mathrm{MB})$ homopolymers were measured and compared with that of iPP (Fig. 2B). For $\mathrm{P}(3 \mathrm{H} 2 \mathrm{MB}), \Delta T\left(54^{\circ} \mathrm{C}\right)$ was small compared to those of $\mathrm{P}(3 \mathrm{HB})\left(111^{\circ} \mathrm{C}\right)$ and PLLA $\left(76^{\circ} \mathrm{C}\right)$ and was closer to that exhibited by commercially available iPP $\left(48^{\circ} \mathrm{C}\right)$.

\section{Crystallization behavior of $\mathrm{P}(3 \mathrm{H} 2 \mathrm{MB})$}

The isothermal crystallization behavior of $\mathrm{P}(3 \mathrm{H} 2 \mathrm{MB})$ was investigated using DSC. The apparent exothermal transition corresponding to crystallization of $\mathrm{P}(3 \mathrm{H} 2 \mathrm{MB})$ could be detected in thermograms recorded at isothermal crystallization temperatures $\left(T_{\mathrm{iso}}\right)$ ranging from 140 to $170{ }^{\circ} \mathrm{C}$. At $T_{\text {iso }}$ values below $140{ }^{\circ} \mathrm{C}$, crystallization started before the sample temperature reached $T_{\text {iso }}$. The shortest half-crystallization time $\left(t_{1 / 2}\right)$ of $\mathrm{P}(3 \mathrm{H} 2 \mathrm{MB})$ might have been observed at $\sim 100{ }^{\circ} \mathrm{C}$, which lies midway between the $T_{\mathrm{g}}$ and $T_{\mathrm{m}}$. The shortest $t_{1 / 2}$ of $\mathrm{P}(3 \mathrm{HB})$ was observed at $\sim 60^{\circ} \mathrm{C}$. The $T_{\text {iso }}$ vs. $t_{1 / 2}$ curve of $\mathrm{P}(3 \mathrm{H} 2 \mathrm{MB})$ shifted by $\sim 30-40{ }^{\circ} \mathrm{C}$ toward higher temperatures compared to that of $\mathrm{P}(3 \mathrm{HB})$. Thus, the crystallization behaviors of $\mathrm{P}(3 \mathrm{H} 2 \mathrm{MB})$ at $140{ }^{\circ} \mathrm{C}$ and $\mathrm{P}(3 \mathrm{HB})$ at $100^{\circ} \mathrm{C}$, including primary nucleation and spherulite growth, were compared. The shortest $t_{1 / 2}$ of $\mathrm{P}(3 \mathrm{H} 2 \mathrm{MB})$ was much shorter than the shortest $t_{1 / 2}$ for $\mathrm{P}(3 \mathrm{HB})$ (Fig. 2C). Whether $\mathrm{P}(3 \mathrm{H} 2 \mathrm{MB})$ exhibits a shorter $t_{1 / 2}$ than iPP is unclear. However, $\mathrm{P}(3 \mathrm{H} 2 \mathrm{MB})$ exhibited a much shorter $t_{1 / 2}$ than PLLA.

To further understand the fast crystallization behavior of $\mathrm{P}(3 \mathrm{H} 2 \mathrm{MB})$, the growth of the $\mathrm{P}(3 \mathrm{H} 2 \mathrm{MB})$ crystals was monitored by POM (Fig. 2D). The $\mathrm{P}(3 \mathrm{H} 2 \mathrm{MB})$ and $\mathrm{P}(3 \mathrm{HB})$ polymers that were melted at $220^{\circ} \mathrm{C}$ for $1 \mathrm{~min}$ were quenched to $T_{i s o}$, after which homogeneous and sporadic crystallization was observed. The spherulites appeared in the molten state. Because the spherulites of $\mathrm{P}(3 \mathrm{H} 2 \mathrm{MB})$ appeared at temperatures above $140{ }^{\circ} \mathrm{C}$, crystallization of $\mathrm{P}(3 \mathrm{H} 2 \mathrm{MB})$ started before the sample temperature reached $T_{\text {iso }}$ when $T_{\text {iso }}$ was below $140^{\circ} \mathrm{C}$. In contrast, spherulites of $\mathrm{P}(3 \mathrm{HB})$ did not appear before the sample temperature reached $T_{\text {iso. }}$. The radial growth rate of spherulites $(G)$ was determined from the temporal increase in the spherulite size at a given $T_{\text {iso. The }} G$ value of $\mathrm{P}(3 \mathrm{H} 2 \mathrm{MB})$ was determined to be $0.91 \mu \mathrm{m} / \mathrm{s}$ at $T_{\text {iso }}=140^{\circ} \mathrm{C}$, and the spherulites of $\mathrm{P}(3 \mathrm{HB})$ grew at a rate of $3.4 \mu \mathrm{m} / \mathrm{s}$ at $T_{\text {iso }}=100^{\circ} \mathrm{C}$. The spherulite morphology of $\mathrm{P}(3 \mathrm{H} 2 \mathrm{MB})$ was much finer than that of $\mathrm{P}(3 \mathrm{HB})$, even in the $30^{\circ} \mathrm{C}$ higher $T_{\text {iso }}$ region (Fig. 2D).

Here, the primary nucleation rates $(I)$ for $\mathrm{P}(3 \mathrm{HB})$ and $\mathrm{P}(3 \mathrm{H} 2 \mathrm{MB})$ were calculated from $\mathrm{POM}$ observations and DSC measurements at the initial stage of crystallization, where crystallization proceeded homogeneously and three-dimensionally (Avrami index $n=4$ ). The obtained 

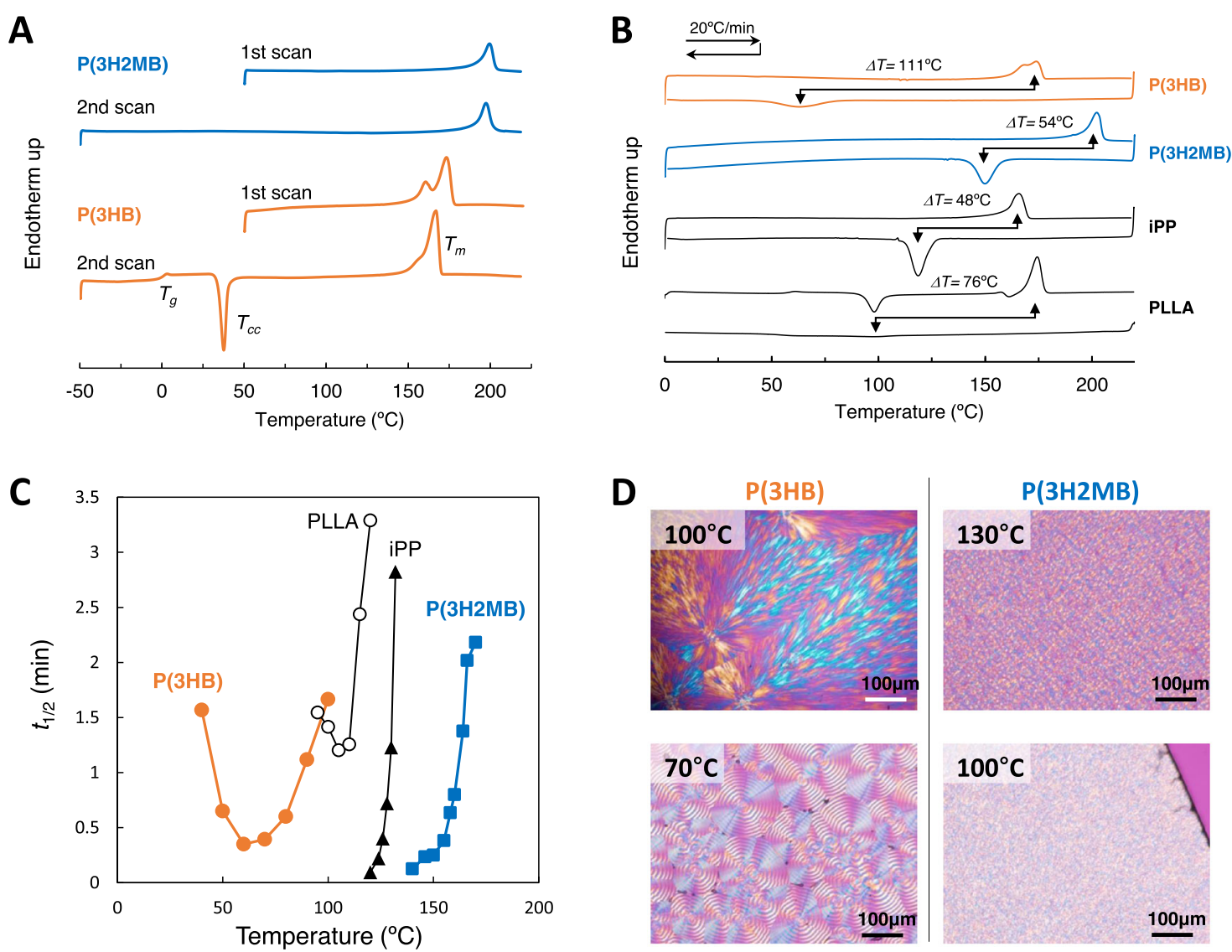

Fig. 2 Melting and crystallization behavior of $\mathbf{P}(3 \mathrm{H} 2 \mathrm{MB})$ homopolymer. $\mathbf{A}$ DSC thermograms of $\mathrm{P}(3 \mathrm{HB})$ and $\mathrm{P}(3 \mathrm{H} 2 \mathrm{MB})$ during the first heating scan from 50 to $220^{\circ} \mathrm{C}$ and the second heating scan from -50 to $220^{\circ} \mathrm{C}$ after rapid quenching from the melt in the first heating scan. B DSC thermograms of polymers during successive heating and cooling scans recorded at $20^{\circ} \mathrm{C} / \mathrm{min}$. The crystallization rates of these polymers were evaluated by the index $\Delta T\left(=T_{\mathrm{m}}-T_{\mathrm{c}}\right)$. C Half-crystallization times $\left(t_{1 / 2}\right)$ of $\mathrm{P}(3 \mathrm{H} 2 \mathrm{MB}), \mathrm{P}(3 \mathrm{HB}), \mathrm{PLLA}$, and iPP at various isothermal crystallization temperatures $\left(T_{\text {iso }}\right)$. D Polarized optical microscope images of $\mathrm{P}(3 \mathrm{HB})$ and $\mathrm{P}(3 \mathrm{H} 2 \mathrm{MB})$ at different $T_{\text {iso }}$ values.

$I$ values for the two polymers are listed in Table 2, together with the spherulite growth rate $(G)$ and Avrami constant $(k)$. Consistent with the number of spherulites, $I$ was much larger for $\mathrm{P}(3 \mathrm{H} 2 \mathrm{MB})$ than for $\mathrm{P}(3 \mathrm{HB})$, despite the higher $T_{\text {iso }}$ of $\mathrm{P}(3 \mathrm{H} 2 \mathrm{MB})$. The $I$ value of $\mathrm{P}(3 \mathrm{H} 2 \mathrm{MB})$ at $140^{\circ} \mathrm{C}$ was much higher than that of $\mathrm{P}(3 \mathrm{HB})$ at $100^{\circ} \mathrm{C}$. Crystallization behavior is dependent on both primary nucleation and spherulite growth. The present results indicate that $\mathrm{P}(3 \mathrm{H} 2 \mathrm{MB})$ exhibited faster primary nucleation than $\mathrm{P}(3 \mathrm{HB})$. Generally, increasing the number density of spherulites is preferred because various properties, such as the transparency, impact resistance, and flexibility of the polymer, tend to be improved in the presence of more spherulites. In many cases, a nucleating agent is applied to promote primary nucleation and improve these properties. However, the present results indicate that $\mathrm{P}(3 \mathrm{H} 2 \mathrm{MB})$ not only has superior thermal properties but also forms an exceptional spherulitic morphology without the addition of a nucleation agent.
Table 2 Kinetic parameters for polymer crystallization.

\begin{tabular}{llllll}
\hline Polymer & $\boldsymbol{T}_{\text {iso }}\left({ }^{\circ} \mathrm{C}\right)$ & $\begin{array}{l}\boldsymbol{n} \\
(-)\end{array}$ & $\begin{array}{l}\boldsymbol{k} \\
\left(\mathbf{m i n}^{-\boldsymbol{n}}\right)\end{array}$ & $\boldsymbol{G}(\boldsymbol{\mu \mathrm { m }} / \mathbf{s})$ & $\boldsymbol{I}\left(\right.$ event $\left./ \mathbf{m m}^{\mathbf{3}} \mathbf{s}\right)$ \\
\hline $\mathrm{P}(3 \mathrm{H} 2 \mathrm{MB})$ & 140 & 3.9 & $1.1 \times 10^{3}$ & 0.91 & $6.3 \times 10^{2}$ \\
$\mathrm{P}(3 \mathrm{H} 2 \mathrm{MB})$ & 150 & 4.1 & $1.2 \times 10^{2}$ & 0.76 & $5.4 \times 10^{2}$ \\
$\mathrm{P}(3 \mathrm{HB})$ & 70 & 3.6 & 71 & 2.6 & 14 \\
$\mathrm{P}(3 \mathrm{HB})$ & 100 & 3.8 & 6.7 & 3.4 & 3.1 \\
\hline
\end{tabular}

$T_{\text {iso }}$ isothermal crystallization temperature, $n$ Avrami index, $k$ Avrami constant, $G$ spherulite growth rate, I primary nucleation rate.

\section{Thermal stability of $\mathrm{P}(3 \mathrm{H} 2 \mathrm{MB})$}

One of the main drawbacks for the use of $\mathrm{P}(3 \mathrm{HB})$ as a biodegradable alternative to common petroleum plastics is that the thermal decomposition temperature is close to its $T_{\mathrm{m}}$, resulting in decomposition of the material during thermal processing. Despite the superior $T_{\mathrm{m}}$ and crystallization behavior of $\mathrm{P}(3 \mathrm{H} 2 \mathrm{MB}), \mathrm{P}(3 \mathrm{H} 2 \mathrm{MB})$ must be 


\section{A}

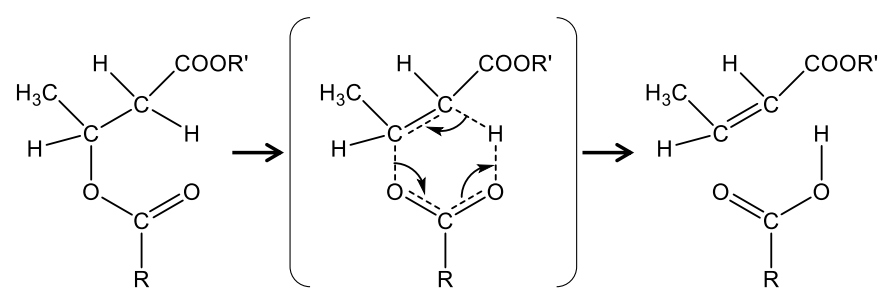

B
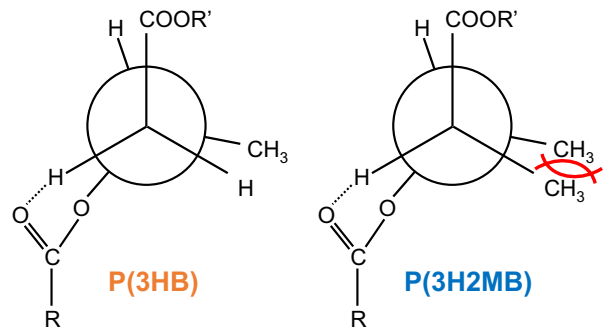

D

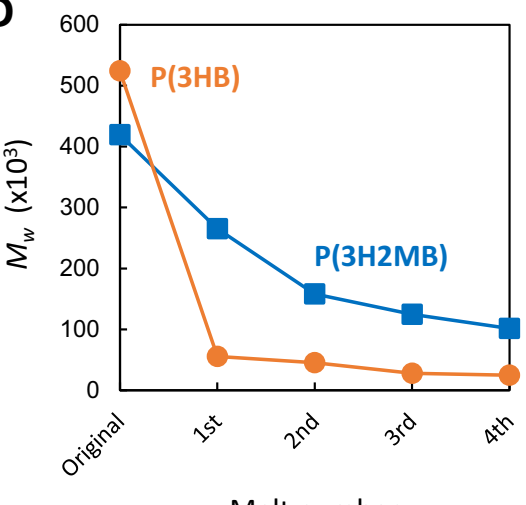

Melt number

Fig. 3 Thermal stability of $\mathbf{P}(\mathbf{3} \mathbf{H} \mathbf{2} \mathbf{M B})$ homopolymer. A Schematic illustration of the cis-elimination reaction in $\mathrm{P}(3 \mathrm{HB})$ and $\mathrm{P}(3 \mathrm{H} 2 \mathrm{MB})$. B Conformations of $\mathrm{P}(3 \mathrm{HB})$ and $\mathrm{P}(3 \mathrm{H} 2 \mathrm{MB})$. Effect of repeat thermal treatments on $\mathbf{C}$ melting temperature $\left(T_{\mathrm{m}}\right)$ and $\mathbf{D}$ weight average molecular weight $\left(M_{w}\right)$ values of $\mathrm{P}(3 \mathrm{HB})$ and $\mathrm{P}(3 \mathrm{H} 2 \mathrm{MB})$.

thermally stable to be applicable. Therefore, the thermal decomposition of $\mathrm{P}(3 \mathrm{H} 2 \mathrm{MB})$ was investigated by thermal gravimetric-differential thermal analysis-mass spectrometry (TG-DTA-MS). The endothermal peaks and accompanying weight change revealed that $\mathrm{P}(3 \mathrm{H} 2 \mathrm{MB})$ degraded at a significantly higher temperature than $\mathrm{P}$ (3HB) (Table 1). The temperature range during which the largest loss of mass occurred was $292^{\circ} \mathrm{C}$ for $\mathrm{P}(3 \mathrm{HB})$, which was associated with the formation of a molecular degradation product with a parent molecular mass $(\mathrm{m} / \mathrm{z})$ of 86 (Supplementary Fig. 5). P(3H2MB) generated a molecular degradation product with a parent molecular mass $(\mathrm{m} / z)$ of 100 at $310^{\circ} \mathrm{C}$ (Supplementary Fig. 6). Based on the mass spectra, $\mathrm{P}(3 \mathrm{H} 2 \mathrm{MB})$ and $\mathrm{P}(3 \mathrm{HB})$ generated 2methylbut-2-enoic acid (tiglic acid) and 2-butenoic acid (crotonic acid), respectively, as the main thermal degradation products. This result indicates that $\mathrm{P}(3 \mathrm{H} 2 \mathrm{MB})$ degrades via the cis-elimination process, similar to the proposed pathway of elimination for $\mathrm{P}(3 \mathrm{HB})$ (Fig. 3A) ${ }^{31}$. For both $\mathrm{P}(3 \mathrm{HB})$ and $\mathrm{P}(3 \mathrm{H} 2 \mathrm{MB})$, no solid residue was detected after thermal degradation at $500^{\circ} \mathrm{C}$. The higher $T_{\mathrm{d} \_ \text {max }}$ observed for $\mathrm{P}(3 \mathrm{H} 2 \mathrm{MB})$ may be attributed to the presence of the $\alpha$-methyl group, which interferes with $\alpha$-deprotonation (Fig. $3 \mathrm{~B}$ ). In the cis-elimination process, the reaction proceeds via a planar six-membered cyclic transition state ${ }^{32}$. In this transition state, the $\alpha$-methyl group and the $\beta$-methyl group are eclipsed, resulting in an energy barrier that is higher than that for $\mathrm{P}(3 \mathrm{HB})$. Moreover, reducing the number of $\alpha$-protons may also restrict cis-elimination. According to this model, $\mathrm{P}[(2 R$, $3 R)-3 \mathrm{H} 2 \mathrm{MB}]$ is expected to generate $(E)$-2-methylbut-2enoic acid (tiglic acid), and $\mathrm{P}[(2 S, 3 R)-3 \mathrm{H} 2 \mathrm{MB}]$ is expected to generate (Z)-2-methylbut-2-enoic acid (angelic acid). The generation of tiglic acid by thermal degradation of $\mathrm{P}(3 \mathrm{H} 2 \mathrm{MB})$ means that the feedstock of $\mathrm{P}(3 \mathrm{H} 2 \mathrm{MB})$ can be recovered from $\mathrm{P}(3 \mathrm{H} 2 \mathrm{MB})$, which may facilitate chemical recycling of $\mathrm{P}(3 \mathrm{H} 2 \mathrm{MB})^{33}$. In typical industrial manufacturing processes, plastics are melted and recrystallized repeatedly for molding into the final products (by pelletizing, compounding, molding, and recycling processes). Such repetitive processes can degrade the polymer, resulting in a reduction in the molecular weight and loss of thermal stability. Therefore, it is important to understand how the resilience of these materials is subject to changes in the thermal conditions to identify adequate substitutes for petroleum-based plastics. The changes in the $T_{\mathrm{m}}$ and molecular weight of $\mathrm{P}(3 \mathrm{H} 2 \mathrm{MB})$ during the cyclic melting and recrystallization processes were 


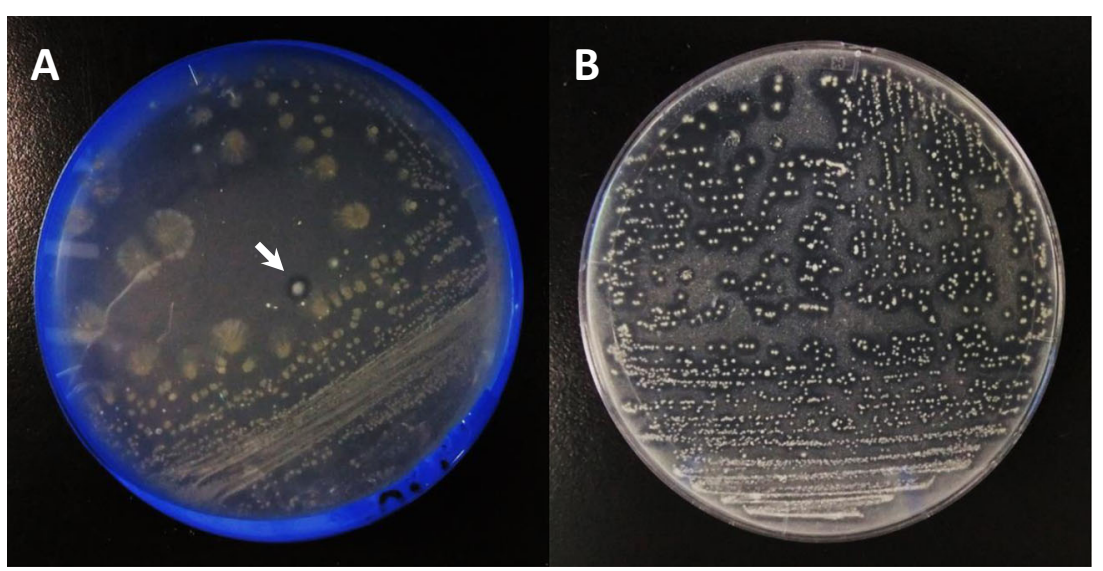

Fig. 4 Biodegradation of $3 \mathrm{H} 2 \mathrm{MB}$-rich polymer. A Biodegradation test by the clear zone method in mineral salt medium agar plates containing low-molecular-weight 3H2MB-rich polymer [P(92 mol\% 3H2MB-co-3HB), $\left.M_{n} \sim 7000\right]$ using microorganisms isolated from on-campus soil (Yokohama City). B The microorganisms indicated by the arrow in panel $(\mathbf{A})$ were spread on a new plate.

evaluated by DSC and GPC. P(3H2MB) displayed superior thermal resilience with a nearly unchanged $T_{\mathrm{m}}$ during four repeat cycles of thermal processing (Fig. 3C). For $\mathrm{P}(3 \mathrm{H} 2 \mathrm{MB})$, the rate of reduction in the molecular weight over time also decreased, demonstrating higher stability for thermal processing (Fig. 3D). Generally, the thermal degradation process proceeds in the molten state. Thus, thermal degradation could be prevented by faster crystallization and a shorter melting time. A smaller difference between the melting point and crystallization temperature (smaller $\Delta T$ ) results in less persistence of the molten state. A smaller crystallization enthalpy is also advantageous for molding in the cooling process. These results indicate that the physical properties of $\mathrm{P}(3 \mathrm{H} 2 \mathrm{MB})$ can alleviate the main drawbacks (e.g., slow crystallization behavior and thermal instability) that have prevented widespread adoption of PHAs as biodegradable thermoplastic substitutes for conventional petroleum-based plastics.

\section{Origin of fast crystallization behavior}

According to thermal dynamic theory, the equation below describes the relationship between the melting temperature and fusion enthalpy in general.

$$
T_{\mathrm{m}}^{0}=\Delta H_{\mathrm{m}}^{0} / \Delta S_{\mathrm{m}}^{0}
$$

Here, $T_{\mathrm{m}}^{0}, \Delta H_{\mathrm{m}}^{0}$, and $\Delta S_{\mathrm{m}}^{0}$ represent the equilibrium melting point, equilibrium fusion enthalpy, and equilibrium fusion entropy, respectively. The melting temperature of $\mathrm{P}(3 \mathrm{H} 2 \mathrm{MB})$ was significantly higher than those of the other PHAs. On the other hand, the fusion enthalpy of $\mathrm{P}(3 \mathrm{H} 2 \mathrm{MB})$ was relatively small compared to that of $\mathrm{P}$ (3HB). Therefore, it is expected that $\mathrm{P}(3 \mathrm{H} 2 \mathrm{MB})$ has a smaller fusion entropy than $\mathrm{P}(3 \mathrm{HB})$.
The most common crystalline structure of $\mathrm{P}(3 \mathrm{HB})$ is an $\alpha$-form with a $2{ }_{1}$-helix conformation (Supplementary Fig. $7)^{34,35}$. According to quantum chemical calculations, the conformation of the repeating unit in the $\mathrm{P}(3 \mathrm{HB}) \alpha$-form crystal (conformation E) is stable for the 5th position among the calculated conformation models, and the conformation that forms the $3_{1}$-helix (conformation $\mathbf{A}$ ) is the most stable (Supplementary Table 1, Supplementary Fig. 8), which is consistent with results of previous stu$\operatorname{dies}^{34,36}$. However, for $\mathrm{P}(3 \mathrm{H} 2 \mathrm{MB})$ with the $\alpha$-methyl group in the $R$-configuration, the most stable conformation was identical to that of the $\mathrm{P}(3 \mathrm{HB}) \alpha$-form crystal (conformation E, Supplementary Table 1, Supplementary Fig. 8). Thermal dynamic theory calculations suggested that the $\mathrm{P}(3 \mathrm{H} 2 \mathrm{MB})$ chains preferentially adopt the $2_{1}$ helix-like conformation, even in the molten state, and that the melting/crystallization transition is accompanied by a small conformational change. Consequently, $\mathrm{P}(3 \mathrm{H} 2 \mathrm{MB})$ may exhibit small entropic changes during melting and rapid formation of crystalline structures during cooling.

\section{Biodegradability of 3H2MB-rich polymer}

Because the aim is to address the issues associated with microplastics generated from traditional plastic materials, the alternative materials must biodegrade in the environment. PHA copolymers consisting of $3 \mathrm{HB}$ and $\alpha$-methylated repeating units such as $3 \mathrm{H} 2 \mathrm{MB}$ or $3 \mathrm{H} 2 \mathrm{MV}$ can be produced by naturally occurring bacteria found in the activated sludge of sewage plants, and these materials are biodegradable ${ }^{11}$. However, whether PHA with a high ratio of $3 \mathrm{H} 2 \mathrm{MB}$ repeating units could be biodegraded by bacteria in the environment is unknown, and there is uncertainty as to whether this could be accomplished because of the stereo-configuration of the $3 \mathrm{H} 2 \mathrm{MB}$ repeating unit. To verify the biodegradability of the $3 \mathrm{H} 2 \mathrm{MB}$-rich polymer, we 
assessed the microbial degradation of the material using a clear zone agar-plate assay with various microbial environmental samples ${ }^{37,38}$. For efficient and high-throughput screening of the microorganisms, a low-molecular-weight $3 \mathrm{H} 2 \mathrm{MB}$-rich polymer $(92 \mathrm{~mol} \% 3 \mathrm{H} 2 \mathrm{MB})$ was synthesized from the $\mathrm{P}(3 \mathrm{H} 2 \mathrm{MB}-\mathrm{co}-3 \mathrm{HB})$ copolymer and used as a polyester powder. The test revealed that some fungi and bacteria were capable of degrading the $3 \mathrm{H} 2 \mathrm{MB}$-rich polymer (Fig. 4). This result indicates that there are microorganisms that can degrade the $3 \mathrm{H} 2 \mathrm{MB}-3 \mathrm{H} 2 \mathrm{MB}$ linkage or at least the $3 \mathrm{H} 2 \mathrm{MB}-3 \mathrm{HB}$ linkage. The isolated microorganisms also degraded the $\mathrm{P}(3 \mathrm{HB})$ polymer. The identification of these microorganisms is currently in progress. The use of these microbes that can degrade $\mathrm{P}[(2 R, 3 R)$ $3 \mathrm{H} 2 \mathrm{MB}]$ in the environment at ambient temperature provides advantages over the use of iPP and PLLA.

\section{Discussion}

Currently, iPP is widely used for various products, such as commodity, packaging, fiber, and automotive products. The prevalence of iPP and other nonbiodegradable plastics in these products exacerbates the global problems posed by microplastics. A solution to these problems is to develop biodegradable plastics that can adequately substitute for iPP and nonbiodegradable plastics. For biodegradable plastics to be used in the same manner as iPP, thermal stability above the $T_{\mathrm{m}}$ and good crystallization behavior must be achieved. As demonstrated in this study, $\mathrm{P}(3 \mathrm{H} 2 \mathrm{MB})$ had the highest $T_{\mathrm{m}}$ among the biosynthesized PHAs and was less susceptible to thermal decomposition and exhibited a faster crystallization behavior than $\mathrm{P}$ (3HB) and PLLA. Furthermore, P(3H2MB) should be biodegradable to some extent in nature. In this study, $\mathrm{P}$ (3H2MB) was biosynthesized using tiglic acid as a precursor; tiglyl-CoA can also be provided intracellularly because it is an intermediate of the isoleucine degradation pathway ${ }^{39}$, indicating that further metabolic engineering may improve the production of this compound from cheap biobased feedstocks. Tiglic acid can also be biosynthesized via the Claisen condensation pathway by thiolase and dehydration by dehydratase. Moreover, depending on the stereoselectivity of $\beta$-ketoacyl-CoA reductase, $\mathrm{P}[(2 R, 3 R)-3 \mathrm{H} 2 \mathrm{MB}]$ could be biosynthesized de novo without going through tiglic acid. In summary, these characteristics point to $\mathrm{P}(3 \mathrm{H} 2 \mathrm{MB})$ as the most promising candidate for high-performance biodegradable plastics from a renewable source that can replace nonbiodegradable plastics. Further development of $\mathrm{P}(3 \mathrm{H} 2 \mathrm{MB})$ will contribute to creating sustainable products and lessen the impact of microplastics on the global environment.

\section{Acknowledgements}

The authors gratefully thank Prof. T. Hata (Tokyo Institute of Technology) for assistance with optical rotation measurements. This work was supported by the Institute for Fermentation, Osaka (IFO) research program (G-2019-3-013 to T.T.), and partially supported by JST-MIRAI (JPMJMI17EC to T.T.)

\section{Author details}

'Department of Materials Science and Engineering, Tokyo Institute of Technology, 4259 Nagatsuta, Midori-ku, Yokohama 226-8502, Japan. ${ }^{2}$ Department of Biological Sciences, College of Science, University of Idaho, 875 Perimeter Dr., Moscow, ID 83844-3010, USA. ${ }^{3}$ Department of Chemistry for Life Sciences and Agriculture, Faculty of Life Sciences, Tokyo University of Agriculture, 1-1-1 Sakuragaoka, Setagaya, Tokyo 156-8502, Japan. ${ }^{4}$ Bioplastic Research Team, RIKEN Center for Sustainable Resource Science, 2-1 Hirosawa, Wako, Saitama 351-0198, Japan

\section{Conflict of interest}

The authors declare no competing interests.

\section{Publisher's note}

Springer Nature remains neutral with regard to jurisdictional claims in published maps and institutional affiliations.

Supplementary information The online version contains supplementary material available at https://doi.org/10.1038/s41427-021-00296-x.

Received: 28 September 2020 Revised: 10 January 2021 Accepted: 27 January 2021.

Published online: 2 April 2021

\section{References}

1. Ogunola, O. S., Onada, O. A. \& Falaye, A. E. Mitigation measures to avert the impacts of plastics and microplastics in the marine environment (a review). Environ. Sci. Pollut. Res. 25, $9293-9310$ (2018).

2. Geyer, R., Jambeck, J. R. \& Law, K. L. Production, use, and fate of all plastics ever made. Sci. Adv. 3, e1700782 (2017).

3. Andrady, A. L. Microplastics in the marine environment. Mar. Pollut. Bull. 62 , 1596-1605 (2011).

4. Mintenig, S. M., Int-Veen, I., Löder, M. G., Primpke, S. \& Gerdts, G. Identification of microplastic in effluents of waste water treatment plants using focal plane array-based micro-Fourier-transform infrared imaging. Water Res. 108, 365-372 (2017).

5. Mason, S. A. et al. L. Microplastic pollution is widely detected in US municipal wastewater treatment plant effluent. Environ. Pollut. 218, 1045-1054 (2016).

6. Sudesh, K, Abe, H. \& Doi, Y. Synthesis, structure and properties of polyhydroxyalkanoates: biological polyesters. Prog. Polym. Sci. 25, 1503-1555 (2000).

7. Jendrossek, D. Microbial degradation of polyesters: a review on extracellular poly(hydroxyalkanoic acid) depolymerases. Polym. Degrad. Stabil. 59, 317-325 (1998).

8. Morohoshi, T., Ogata, K., Okura, T. \& Sato, S. Molecular characterization of the bacterial community in biofilms for degradation of poly(3-hydroxybutyrate-co3-hydroxyhexanoate) films in seawater. Microbes Environ. 33, 19-25 (2018).

9. Martin, R. T., Camargo, L. P. \& Miller, S. A. Marine-degradable polylactic acid. Green Chem. 16, 1768-1773 (2014).

10. Narancic, T. et al. Biodegradable plastic blends create new possibilities for endof-life management of plastics but they are not a panacea for plastic pollution. Environ. Sci. Technol. 52, 10441-10452 (2018).

11. Satoh, H., Mino, T. \& Matsuo, T. Anaerobic uptake of glutamate and aspartate by enhanced biological phosphorus removal activated sludge. Water Sci. Technol. 37, 579-582 (1998).

12. Dai, Y., Lambert, L., Yuan, Z. \& Keller, J. Characterization of polyhydroxyalkanoate copolymer with controllable four-monomer composition. J. Biotechnol. 134, 137-145 (2008).

13. Michinaka, A., Arou, J., Onuki, M., Satoh, H. \& Mino, T. Analysis of polyhydroxyalkanoate (PHA) synthase gene in activated sludge that produces PHA containing 3-hydroxy-2-methylvalerate. Biotechnol. Bioeng. 96, 871-880 (2007).

14. Watanabe, Y., Ishizuka, K., Furutate, S., Abe, H. \& Tsuge, T. Biosynthesis and characterization of novel poly(3-hydroxybutyrate-co-3-hydroxy-2-methylbutyrate): thermal behavior associated with a-carbon methylation. RSC Adv. 5, 58679-58685 (2015) 
15. Dong, H., Liffland, S., Hillmyer, M. A. \& Chang, M. C. Y. Engineering in vivo production of a-branched polyesters. J. Am. Chem. Soc. 141, 16877-16883 (2019).

16. Tappel, R. C., Wang, Q. \& Nomura, C. T. Precise control of repeating unit composition in biodegradable poly(3-hydroxyalkanoate) polymers synthesized in Escherichia coli. J. Biosci. Bioeng. 114, 480-486 (2012).

17. Furutate, S. et al. Biosynthesis and characterization of novel polyhydroxyalkanoate copolymers consisting of 3-hydroxy-2-methylbutyrate and 3hydroxyhexanoate. J. Polym. Res. 24, 221-229 (2017).

18. Ushimaru, K., Watanabe, Y., Hiroe, A. \& Tsuge, T. A single-nucleotide substitution in phasin gene leads to enhanced accumulation of polyhydroxyalkanoate (PHA) in Escherichia coli harboring Aeromonas caviae PHA biosynthetic operon. J. Gen. Appl. Microbiol. 61, 63-66 (2015).

19. Taguchi, S. et al. A microbial factory for lactate-based polyesters using a lactate-polymerizing enzyme. Proc. Natl Acad. Sci. USA 105, 17323-17327 (2008).

20. Green, M. R. \& Sambrook, J. Molecular Cloning: A Laboratory Manual (Cold Spring Harbor Laboratory, USA, 2012).

21. Tezuka, Y., Ishii, N., Kasuya, K. \& Mitomo, H. Degradation of poly(ethylene succinate) by mesophilic bacteria. Polym. Degrad. Stabil. 84, 115-121 (2004).

22. Fadzil, F. I. M., Mizuno, S., Hiroe, A., Nomura, C. T. \& Tsuge, T. Low carbon concentration feeding improves medium-chain-length polyhydroxylakanoate biosynthesis in Escherichia coli strains with defective $\beta$-oxidation. Front. Bioeng. Biotechnol. 6, 178 (2018).

23. Tappel, R. C., Kucharski, J. M., Mastroianni, J. M., Stipanovic, A. J. \& Nomura, C. T. Biosynthesis of poly[(R)-3-hydroxyalkanoate] copolymers with controlled repeating unit compositions and physical properties. Biomacromolecules 13, 2964-2972 (2012)

24. Tsuge, T. Metabolic improvement and use of inexpensive carbon sources in microbial production of polyhydroxyalkanoates. J. Biosci. Bioeng. 94, 579-584 (2002).

25. Monasse, B. \& Haudin, J. M. Growth transition and morphology change in polypropylene. Colloid Polym. Sci. 263, 822-831 (1985).

26. Eawwiboonthanakit, N., Jaafar, M., Hamid, Z. A. A., Todo, M. \& Lila, B. Tensile properties of poly(L-lactic) acid (PLLA) blends. Adv. Mater. Res. 1024, 179-183 (2014).
27. Tai, A. \& Imaida, M. The stereochemistry of 3-hydroxy-2-methylbutyric acid Bull. Chem. Soc. Jpn. 51, 1114-1117 (1978).

28. Hisano, T. et al. Crystal structure of the (R)-specific enoyl-CoA hydratase from Aeromonas caviae involved in polyhydroxyalkanoate biosynthesis. J. Biol. Chem. 278, 617-624 (2003).

29. Greco, P. \& Martuscelli, E. Crystallization and thermal behaviour of poly(D(-)-3hydroxybutyrate)-based blends. Polymer 30, 1475-1483 (1989).

30. Zhu, C., Nomura, C. T., Perrotta, J. A., Stipanovic, J. \& Nakas, J. P. The effect of nucleating agents on physical properties of poly-3-hydroxybutyrate (PHB) and poly-3-hydroxybutyrate-co-3-hydroxyvalerate ( $\mathrm{PHB}-\mathrm{CO}-\mathrm{HV}$ ) produced by Burkholderia cepacia ATCC 17759. Polym. Test. 31, 579-585 (2012).

31. Abe, $H$. Thermal degradation of environmentally degradable poly(hydroxyalkanoic acid)s. Macromol. Biosci. 6, 469-486 (2006).

32. Kopinke, F. D., Remmler, M. \& Mackenzie, K. Thermal decomposition of biodegradable polyesters-l: Poly(b-hydroxybutyric acid). Polym. Degrad. Stabil. 52, 25-38 (1996).

33. Sato, S., Ishii, N., Hamada, Y., Abe, H. \& Tsuge, T. Utilization of 2-alkenoic acids for biosynthesis of medium-chain-length polyhydroxyalkanoates in metabolically engineered Escherichia coli to construct a novel chemical recycling system. Polym. Degrad. Stabil. 97, 329-336 (2012).

34. Li, Y. X. \& Wu, Y. D. Theoretical study on the structure of poly((R)-3-hydroxybutanoic acid). J. Phys. Chem. A 107, 5128-5137 (2003).

35. Yokouchi, M., Chatani, H., Tadokoro, K., Teranishi, K. \& Tani, H. Structural studies of polyesters: 5 . Molecular and crystal structures of optically active and racemic poly(ß-hydroxybutyrate). Polymer 14, 267-272 (1973).

36. Sasanuma, Y. \& Katsumata, S. Elucidation of conformational characteristics and configurational properties of poly((R)-3-hydroxybutyrate) by ab initio statistical mechanics. Polym. J. 45, 727-737 (2013).

37. Mergaert, J. \& Swings, J. Biodiversity of microorganisms that degrade bacterial and synthetic polyesters. J. Ind. Microbiol. 17, 463-469 (1996).

38. Kasuya, K. et al. Characterization of a mesophilic aliphatic-aromatic copolyester-degrading fungus. Polym. Degrad. Stabil. 94, 1190-1196 (2009).

39. Füchtenbusch, B., Fabritius, D. \& Steinbüchel, A. Incorporation of 2-methyl-3hydroxybutyric acid into polyhydroxyalkanoic acids by axenic cultures in defined media. FEMS Microbiol. Lett. 138, 153-160 (1996).

40. Garlotta, D. A literature review of poly(lactic acid). J. Polym. Environ. 9, 63-84 (2001). 